\title{
Thermo-Physical Properties Measurement of Advanced TBC Materials with Pyrochlore and Perovskite Structures NOVEED Ejaz ${ }^{1, a^{*}}$, LIAQAT Ali ${ }^{1, b}$, AKHLAQ Ahmed ${ }^{1, c}$, MUHAMMAD Mansoor, ${ }^{2, \mathrm{~d}}$, MUHAMMAD Muneeb Asim ${ }^{3, \mathrm{~d}}$, ABDUL Rauf ${ }^{2, e}$, KHALID Mehmood $^{2, f}$
}

\author{
${ }^{1}$ Department of Metallurgical and Materials Engineering, \\ University of Engineering and Technology, Lahore, Pakistan, \\ ${ }^{2}$ Institute of Industrial Control Systems, Rawalpindi, Pakistan \\ ${ }^{3}$ NanoSciences \& Technology Department, NCP, Islamabad, Pakistan \\ anoveedejaz@gmail.com, bliaqat_kasuri@uet.edu.pk, caamalik87@hotmail.com, \\ dmalik01677@yahoo.com, dmmasim20@gmail.com, eabdulrauf2971@yahoo.com, \\ fengrkhalid80@yahoo.com
}

\section{Keywords: Thermal Conductivity, Perovskite, Pyrochlore, YSZ, TEC}

\begin{abstract}
Thermal barrier coatings (TBCs) serve as thermal insulator in the hot region of an aircraft engine.Besides this, it also protects the underlying metal surface from the harsh corrosive and eroding environment. The associated lower thermal conductivity of TBC ceramic materials plays an important role in the improvement of thermal efficiency of the engine in term of increased combustion temperature and power. The thermal conductivity of the conventional yttria stabilized zirconia (YSZ) and three advanced ceramic materials with perovskite $\left(\mathrm{CaZrO}_{3}\right)$ andpyrochlore structure $\left.\left(\mathrm{La}_{0.75} \mathrm{Nd}_{0.25}\right)_{2} \mathrm{Zr}_{2} \mathrm{O}_{7} \& \mathrm{Nd}_{2} \mathrm{Ce}_{2} \mathrm{O}_{7}\right)$ have been determined using differential scanning calorimetry (DSC). With thin metallic disk on the ceramic samples of different heights were heated / scanned using a standard DSC apparatus. The results were evaluated for the thermal conductivity measurement using well established procedure/calculations. The analyzed results were compared with that of other techniques given by other researchers and found to be in good agreement with an error of $10-15 \%$. The result of coefficient of thermal expansion (TEC) that was measured using a dilatometer up to $1273 \mathrm{~K}$ has also given.
\end{abstract}

\section{Introduction}

Thermal barrier coatings (TBCs) not only protects the underlying metal surface from the harsh corrosive and eroding environment, but also it serves as thermal insulator in the hot region of an aircraft engine. The purpose of high temperature thermal stability and the need for lower thermal conductivity enhancing the turbine inlet temperature (TIT) is the drive for the improvement in the existing materials associating research and development of new more durable materials. As an outcome, number of high potential materials such as pyrochlores, perovskites and hexa-aluminates have been researched and explored for various required properties [1-4]. The associated lower thermal conductivity of TBC ceramic materials plays an important role in the improvement of thermal efficiency of the engine in term of increased combustion temperature. Although the state of art $8 \%$ yttria stabilized zirconia (YSZ) is generally used as a standard TBC in aircraft engines and power generation turbines due to its excellent thermal and mechanical properties (e.g., low thermal conductivity, higher TEC, fracture toughness and thermal fatigue life) [5-7], it has limitation of application temperature which is below $1200^{\circ} \mathrm{C}$ due to tetragonal to monoclinic polymorphic phase transformation. Therefore, the need of advanced gas turbines operating at $+1500^{\circ} \mathrm{C}$ drove the newer research for more efficient ceramics showing higher compatibility with bond-coat, high temperature structural stability and lower thermal conductivity. The ceramics with perovskite and pyrochlore crystal structure have earned great attention for advanced TBC applications due to their higher melting point, high temperature structural stability (up to melting point of substrate) and low thermal conductivity [8-19]. In the present study, the thermal conductivity of the standard $8 \%$ yttria 
stabilized zirconia (YSZ) and three advanced ceramic materials with perovskite and pyrochloretype crystal structurehave been determined using differential scanning calorimetry (DSC). These materials are: (i) calcium zirconate $\left(\mathrm{CaZrO}_{3}\right.$, perovskite type orthorhombic crystal structure), (ii) neodymium doped lanthanum zirconate $\left(\mathrm{La}_{0.75} \mathrm{Nd}_{0.25}\right)_{2} \mathrm{Zr}_{2} \mathrm{O}_{7}$, pyrochlore type crystal structure) and (iii) Neodymium cerate $\left(\mathrm{Nd}_{2} \mathrm{Ce}_{2} \mathrm{O}_{7}\right.$, fluorite type crystalstructure). Crystal structure of all of them is stable at higher temperature $\left(+1600^{\circ} \mathrm{C}\right)$ with comparatively lower thermal conductivity than YSZ[20]. They also have very promising thermo physical properties required for advanced TBCs[21-30].

Many techniques are used for thermal conductivity measurements of low conductivity material and TBC ceramics such as laser flash method [31-33], infrared thermographictechnique [34-37], differential scanning calorimeter (DSC) $[38,39]$ and modulated temperature differential scanning calorimeter (MTDSC) [40-42]. In the present study, the thermal conductivity of the sintered samples of the TBC ceramics was measured using DSC with thin metallic disk on ceramic sample. It is comparatively simpler and economical method as a simple DSC equipment is used without need of expensive modulated temperature facility. In this method, a thin copper disk on the ceramic samples of different heights were heated / scanned using a standard DSC apparatus. The wellestablished theory and procedure of Camirand,C.P. [38] was used to evaluate the results for thermal conductivity measurement. The analyzed results were also compared with that of other techniques given by other researchers. The thermal expansion coefficient (TEC) is also an important property of the TBC ceramics. A higher TEC of the ceramic topcoat is generally required for better compatibility with bondcoat for better thermo mechanical fatigue life. It was measured using a high temperature dilatometer.

\section{Experimental Setup and Results}

Yttria Stabilized Zirconia $\left(\mathrm{ZrO}_{2} .8 \mathrm{Y}_{2} \mathrm{O}_{3} \mathrm{YSZ}\right)$ and the Calcuim Zirconate $\left(\mathrm{CaZrO}_{3}\right)$ were standard products manufactured by Oerlikon Metco with the trade name of METCO 204B-NS and METCO 211, respectively. Neodymium doped lanthanum zirconate $\left(\mathrm{La}_{0.75} \quad \mathrm{Nd}_{0.25}\right)_{2} \mathrm{Zr}_{2} \mathrm{O}_{7}$ was synthesized by solid state reaction route [43-44] using $+99.9 \%$ pure powders of lanthana (lanthanum (III) oxide, $\mathrm{La}_{2} \mathrm{O}_{3}$ ), neodymia (neodymium (III) oxide, $\mathrm{Nd}_{2} \mathrm{O}_{3}$ ), and zirconia (zirconium(IV) oxide, $\mathrm{ZrO}_{2}$ ) supplied by Sigma-Aldrich. For the purpose, the weights of the three powders were calculated in the stoichiometric ratio in accordance to $\left.\left(\mathrm{La}_{0.75} \mathrm{Nd}_{0.25}\right)_{2} \mathrm{Zr}_{2} \mathrm{O}_{7}\right)$ and their mixture was milled in the zirconia jar using high energy planetary ball mill for 6 hours with zirconia balls. Afterward, the powders were reacted at $1650^{\circ} \mathrm{C}$ for 10 hours with heating / cooling rate of $3^{\circ} \mathrm{C} / \mathrm{min}$. Similar procedures was used to synthesize the neodymium cerate $\left(\mathrm{Nd}_{2} \mathrm{Ce}_{2} \mathrm{O}_{7}\right)$ using $+99.9 \%$ pure powders of Ceria (Cerium (IV) oxide, $\mathrm{CeO}_{2}$ ), neodymia (neodymium (III) oxide, $\mathrm{Nd}_{2} \mathrm{O}_{3}$ ) supplied by the Sigma-Aldrich.

Sample Preparation.For thermal conductivity measurements, five samples of each four TBC ceramic material enlisted below was prepared with different thicknesses $(0.5$ to $2 \mathrm{~mm})$ and $3 \mathrm{~mm}$ diameter by using different weights in the die during green compaction. The procedure used in the preparation of the samples is given in the flow chart given in Fig. 1a.

1. Yttria stabilized zirconia (YSZ)

2. Calcium Zirconate $\left(\mathrm{CaZrO}_{3}\right)$

3. Neodymium doped Lanthanum Zirconate $\left.\left(\mathrm{La}_{0.75} \mathrm{Nd}_{0.25}\right)_{2} \mathrm{Zr}_{2} \mathrm{O}_{7}\right)$

4. Neodymium Cerate $\left(\mathrm{Nd}_{2} \mathrm{Ce}_{2} \mathrm{O}_{7}\right)$

Fig. $1 \mathrm{~b}$ shows the sintering cycle adopted during sample preparation. The extremely slow heating rate $\left(1{ }^{\circ} \mathrm{C} / \mathrm{min}\right)$ at the initial stage and hold at $300^{\circ} \mathrm{C}$ is to drive out the binder from the green compact without inducing crack in the sample. The remaining heating and cooling rate was kept $3^{\circ} \mathrm{C} / \mathrm{min}$ which is also slow enough to prevent the cracking in the ceramic samples. Fig. 1c shows stereo microscope image of the sintered samples of $\mathrm{Nd}_{2} \mathrm{Ce}_{2} \mathrm{O}$; the variation in the thickness of the samples is evident. The metallic pure copper disk samples were prepared from the $0.3 \mathrm{~mm}$ sheet using $3 \mathrm{~mm}$ dia punching die. 

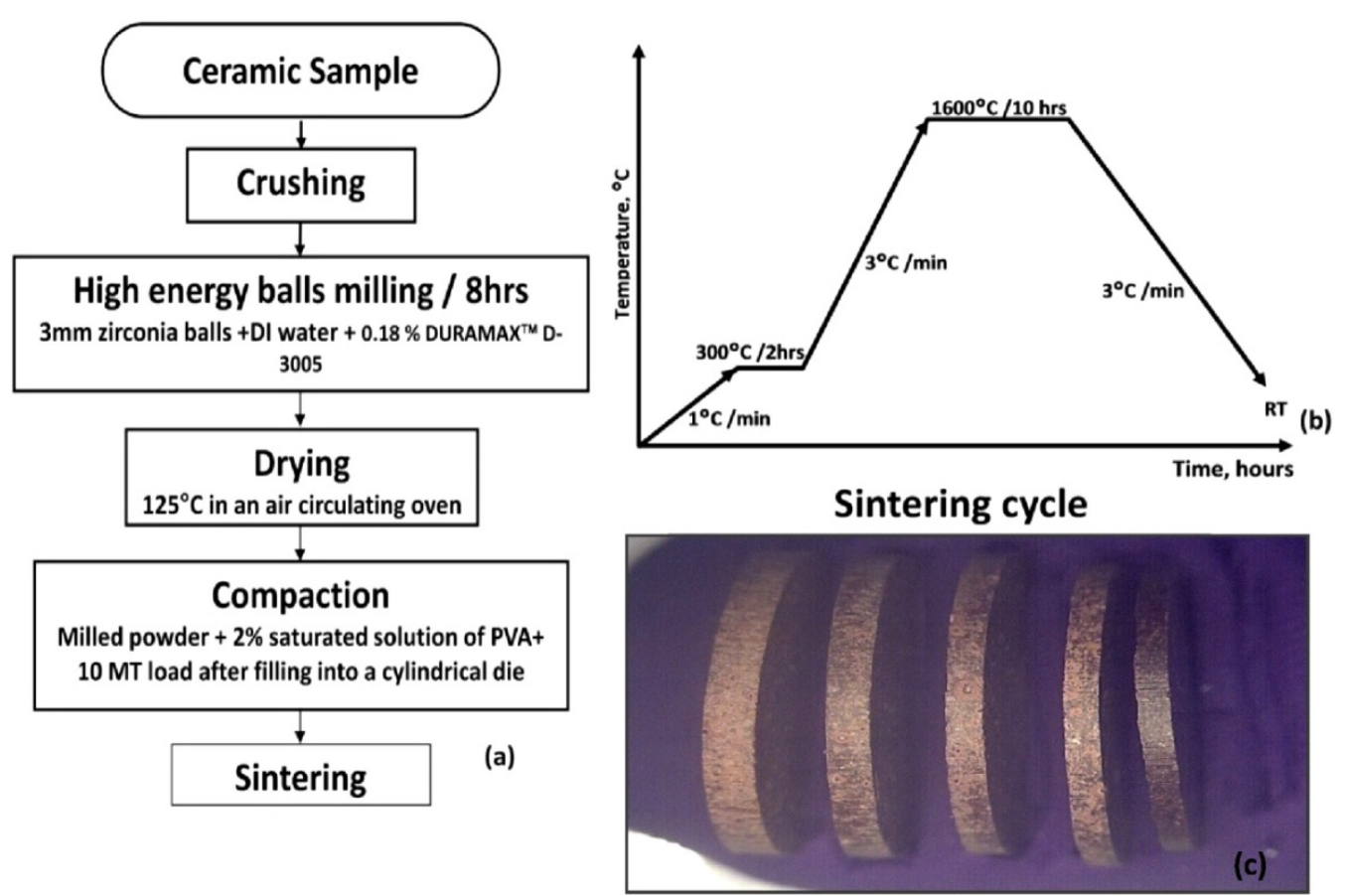

Fig. 1. a) Flow chart showing the procedure for ceramic samples preparation, b) sintering cycle, c) stereomicroscopic image of sintered samples of $\mathrm{Nd}_{2} \mathrm{Ce}_{2} \mathrm{O}_{7}$ revealing different thickness of each sample

After measuring the weight and dimension of the ceramic samples and copper disk, DSC scans were taken by placing the metallic disk on the ceramic sample in one crucible of the DSC apparatus and leaving the other one empty. For thermal expansion measurement, cylindrical ceramic samples of four TBC materials with $25 \mathrm{~mm}$ height and $9 \mathrm{~mm}$ dia were prepared using the similar procedure given in the Fig. 1.

Thermal Conductivity Measurement. The theory of measurement of the thermal conductivity of a ceramic using DSC is based upon melting of a thin metallic disk onto the ceramic samples of different heights or thicknesses; the variation in the thickness of ceramic samples affect the heat flow from DSC furnace to metal disk, effecting the slope of melting curve with a time-base shift in its differential power, $\mathrm{dP}$.

After measuring the size and the dimensions of the metallic copper disk and ceramic sample, the metallic disk was placed over the ceramic sample as per schematic shown in the Fig. 2a. Fig. $2 b$ shows thermal resistances at contact regions in the cross sectional view. When the metallic sample is place on the top of the ceramic sample, the total thermal resistance $\mathrm{R}_{\mathrm{T}}$ is:

$$
\mathrm{R}_{\mathrm{T}}=\mathrm{R}_{1}+\mathrm{R}_{2}+\mathrm{R}_{\mathrm{c}}
$$

Where $R_{1}$ is thethermal resistance at $\mathrm{Cu}$ disk to ceramic sample interface, $\mathrm{R}_{2}$ is the thermal resistance at DSC crucible to ceramic sample interface and $R_{c}$ is the thermal resistance of ceramic sample.

Before running the actual sample, a zero-line curve was obtained initially with the empty furnaces of DSC which was subsequently subtracted from the actual test curves.

A fast scan $\sim 15{ }^{\circ} \mathrm{C} / \mathrm{min}$ was carried out to minimize the convection effects in the furnace with the typical melting curve of pure metal (Fig.3).

The slope of the increasing part of the $\mathrm{dP} / \mathrm{dT}$ curve is inversely proportional to the total thermal resistance, $\mathrm{R}_{\mathrm{T}}$. 


$$
\mathrm{S}=\mathrm{dP} / \mathrm{dT}=2 / \mathrm{R}_{\mathrm{T}}
$$

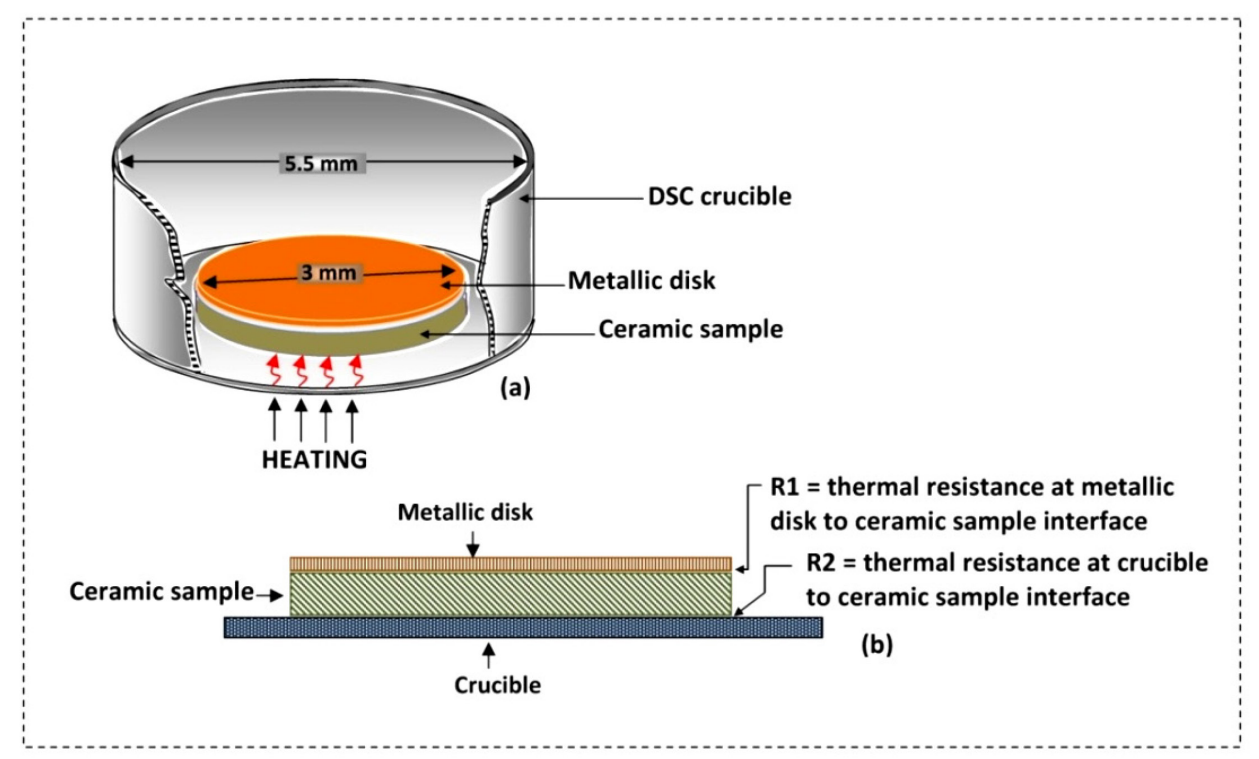

Fig. 2. a) Schematic showing the placement of the ceramic sample and metallic disk in DSC crucible, b) cross sectional view revealing the thermal resistances at contact regions

Fig. 3. Characteristic DSC curve achieved with ceramic sample with metallic disk at top surface

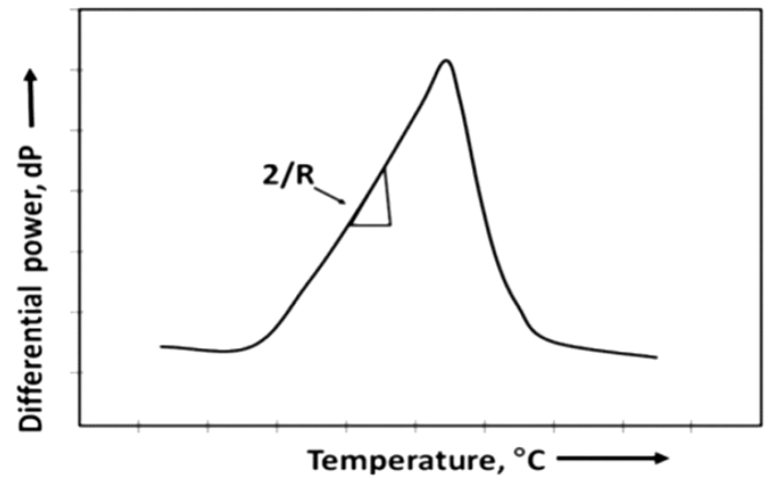

The thermal resistance of the ceramic sample, $\mathrm{R}_{\mathrm{c}}$ is proportional to the thickness-to-area ratio of ceramic sample.

$$
\operatorname{Rc} \propto \mathrm{t} / \mathrm{A}
$$

Where $\mathrm{t}$ and $\mathrm{A}$ is the thickness and area of the ceramic sample, respectively, and

$$
\mathrm{R}_{\mathrm{c}}=1 / \lambda \times \mathrm{t} / \mathrm{A}
$$

Here, $\lambda$ is the thermal conductivity of ceramic sample.

The $\mathrm{R}_{1}+\mathrm{R}_{2}$ is a constant resistance and it was kept at minimum by making the ceramic and metallic samples with very flat and smooth surface. Before each scan, a preliminary slow scan was also run in order to completely fuse the metallic sample onto the ceramic sample; it help to reduce the thermal resistance at metallic $\mathrm{Cu}$ disk to ceramic sample. Total thermal resistance was calculated using Eq.2 from five scans of ceramic samples with different known thicknesses and constant surface area (ca. $3 \mathrm{~mm}$ ) and plotted against respective $\mathrm{t} / \mathrm{A}$ ratio of the samples as shown in the Fig. 4. The inverse of slope of this linear plot derives the thermal conductivity as per equation (4). The results are given in the Table 1. 
Thermal Expansion Measurements. Samples were tested using a dilatometer up to $1200^{\circ} \mathrm{C}$ with $10^{\circ} \mathrm{C} /$ min heating rate. Fig. 5a shows the sintered sample of the $\mathrm{Nd}_{2} \mathrm{Ce}_{2} \mathrm{O}_{7}$ revealing its cyliderical shape $(\phi 9 \mathrm{~mm} \times 25 \mathrm{~mm})$. The percentage linear change $\left(\mathrm{dL} / \mathrm{L}_{\mathrm{o}} \%\right.$, where $\mathrm{dL}$ is change in length and $\mathrm{L}_{\mathrm{o}}$ is original length) wasplotted against the temperature as shown in the Fig. $5 \mathrm{~b}$.
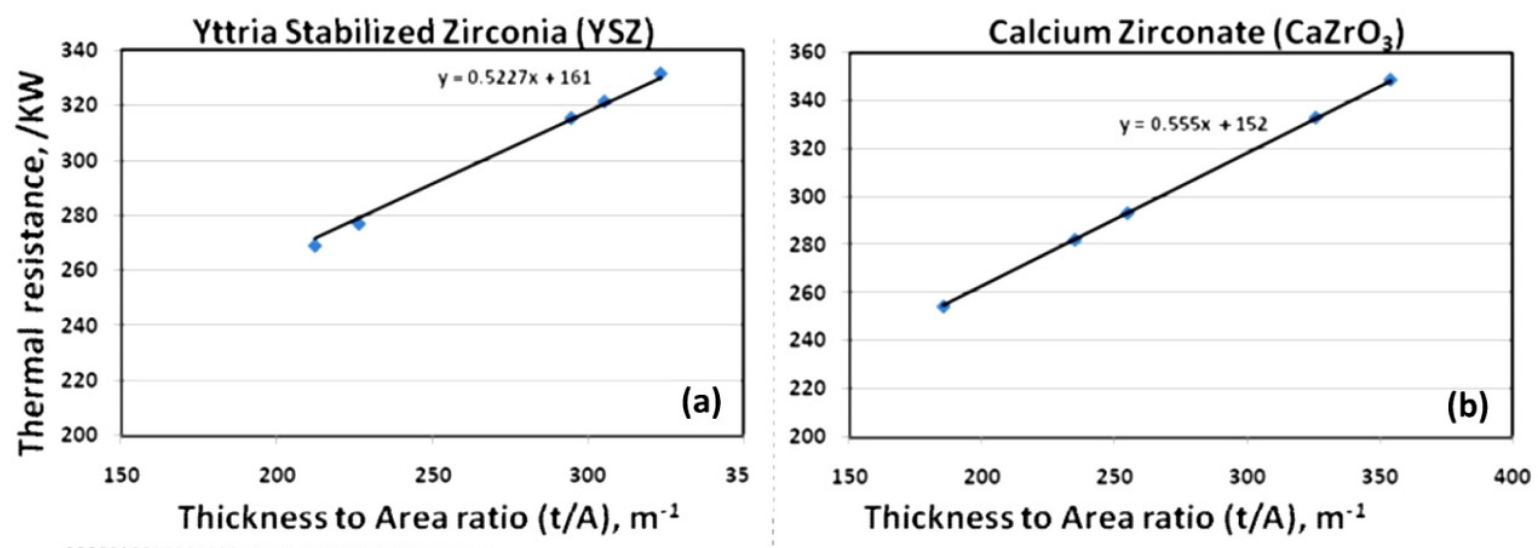

Neodymium doped Lanthanum Zirconate
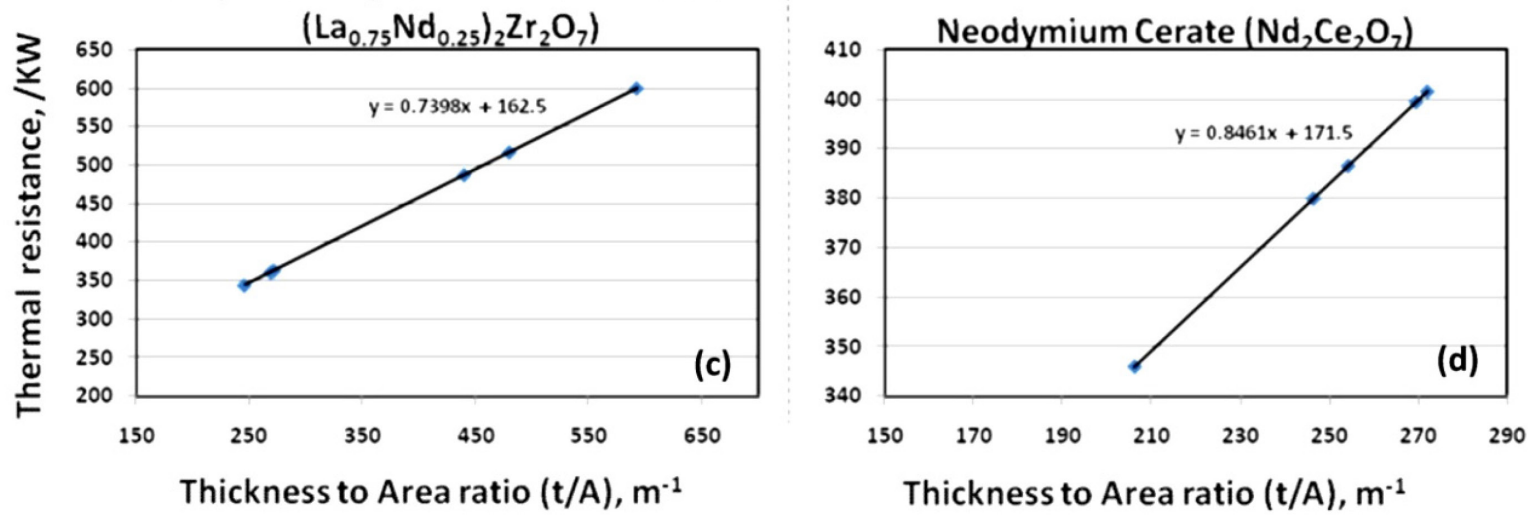

Fig. 4. Plot of the total thermal resistance verses thickness to area ratio; a) Yttria stabilized zirconia (YSZ),

b) Calcium Zirconate $\left(\mathrm{CaZrO}_{3}\right)$, c) Neodymium doped Lanthanum Zirconate $\left.\left(\mathrm{La}_{0.75} \mathrm{Nd}_{0.25}\right)_{2} \mathrm{Zr}_{2} \mathrm{O}_{7}\right)$,

d) Neodymium Cerate $\left(\mathrm{Nd}_{2} \mathrm{Ce}_{2} \mathrm{O}_{7}\right)$

Table 1. Experimental results of thermal conductivity calculations with theoretical values

\begin{tabular}{|c|c|c|c|c|c|}
\hline Sample & Slope & $\begin{array}{c}\text { Total } \\
\text { Thermal } \\
\text { Resistance, } \\
\mathbf{R}_{\mathbf{T}}\end{array}$ & $\begin{array}{c}\text { Thermal } \\
\text { conductivity, } \\
\lambda \text { (DSC) } \\
\text { [W/mK] }\end{array}$ & $\begin{array}{c}\text { Thermal } \\
\text { conductivity } \\
\text { (literature) } \\
{[\mathbf{W} / \mathbf{m K}]}\end{array}$ & $\begin{array}{c}\text { Difference } \\
\text { from } \\
\text { literature } \\
{[\%]}\end{array}$ \\
\hline $\mathrm{YSZ}$ & 0.526 & 161 & 1.9 & $2.2[5-7]$ & 13 \\
\hline $\mathrm{CaZrO}_{3}$ & 0.556 & 152 & 1.8 & $2.0[20]$ & 10 \\
\hline$\left(\mathrm{La}_{0.75} \mathrm{Nd}_{0.25}\right)_{2} \mathrm{Zr}_{2} \mathrm{O}_{7}$ & 0.741 & 163 & 1.35 & $\mathrm{NA}$ & - \\
\hline $\mathrm{Nd}_{2} \mathrm{Ce}_{2} \mathrm{O}_{7}$ & 0.855 & 172 & 1.17 & $1.6[45]$ & 26 \\
\hline
\end{tabular}




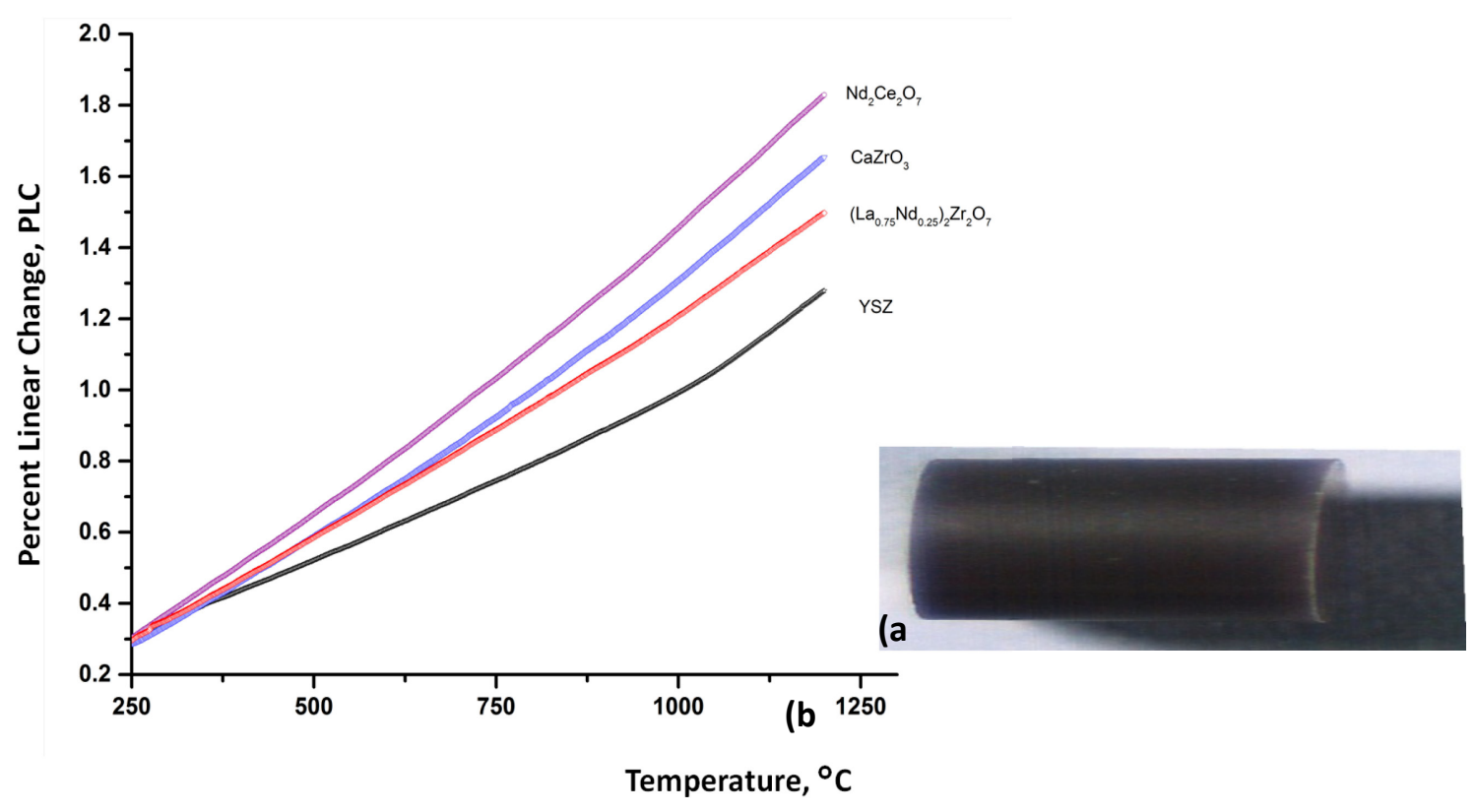

Fig. 5. The sintered sample of Neodymium Cerate $\left(\mathrm{Nd}_{2} \mathrm{Ce}_{2} \mathrm{O}_{7}\right)$ used in the dilatometer test, b)plot of percent linear change verses temperature for Yttria stabilized zirconia (YSZ),Calcium Zirconate $\left(\mathrm{CaZrO}_{3}\right)$, Neodymium doped Lanthanum Zirconate $\left.\left(\mathrm{La}_{0.75} \mathrm{Nd}_{0.25}\right)_{2} \mathrm{Zr}_{2} \mathrm{O}_{7}\right)$ and Neodymium Cerate $\left(\mathrm{Nd}_{2} \mathrm{Ce}_{2} \mathrm{O}_{7}\right)$

The Thermal expansion coefficient (TEC) of TBC materials was also measured using the following equation:

$$
T E C=\frac{1}{L_{o}} \cdot \frac{d L_{1}-d L_{o}}{T_{1}-T_{o}}
$$

Where $L_{o}$ is the length of the sample at $T_{o}, d L_{o}$ is the change in length at $T_{o}, d L_{1}$ is the change in length at $T_{1}$. The results of the TEC are given in the Table 2 . The neodymium cerate $\left(\mathrm{Nd}_{2} \mathrm{Ce}_{2} \mathrm{O}_{7}\right)$ showed the highest expansion which may be attributed to the increase in the structure disorder due to presence of comparatively higher atom size $(\mathrm{Nd})$ in rare earth (RE) cerate $\left(\mathrm{RE}_{2} \mathrm{Ce}_{2} \mathrm{O}_{7}\right)$ causing in formation of ionic vacancy clustering [46].

Table 2. Thermal expansion coefficient of various TBC materials

\begin{tabular}{|c|c|}
\hline Sample & TEC (at 1273K) X $10^{-6}[/ \mathrm{K}]$ \\
\hline YSZ & 10.2 \\
\hline $\mathrm{CaZrO}_{3}$ & 12.4 \\
\hline$\left(\mathrm{La}_{0.75} \mathrm{Nd}_{0.25}\right)_{2} \mathrm{Zr}_{2} \mathrm{O}_{7}$ & 11.36 \\
\hline $\mathrm{Nd}_{2} \mathrm{Ce}_{2} \mathrm{O}_{7}$ & 13.5 \\
\hline
\end{tabular}

The TEC of the calcium zirconate $\left(\mathrm{CaZrO}_{3}\right)$ was also higher than that of yttria stabilized zirconia (YSZ). While the TEC of the neodymium doped lanthanum zirconate $\left.\left(\mathrm{La}_{0.75} \mathrm{Nd}_{0.25}\right)_{2} \mathrm{Zr}_{2} \mathrm{O}_{7}\right)$ was comparable with the YSZ. the TEC of the lanthanum zirconate $\left(\mathrm{La}_{2} \mathrm{Zr}_{2} \mathrm{O}_{7}\right)$ is lower $(\mathrm{TEC}, 9.1$ $\mathrm{x} 10^{-6} /{ }^{\circ} \mathrm{K}$ at $\left.1000^{\circ} \mathrm{C}\right)$ [47] than $8 \% \mathrm{YSZ}\left(10.7 \times 10^{-6} /{ }^{\circ} \mathrm{K}\right.$ at $\left.25-1000^{\circ} \mathrm{C}\right)$ [28] which shows may induce the thermal stresses in the coating during operation $[28,48]$. The doping of neodymium in the lanthanum zirconate $\left(\mathrm{La}_{2} \mathrm{Zr}_{2} \mathrm{O}_{7}\right)$ caused the marked improvement in the TEC, making it compatible choice with YSZ (for engineering double ceramic layered or composition gradient thermal barrier coatings). 


\section{Summary}

DSC is comparatively simple method to measure the thermal conductivity of ceramics materials with $10-15 \%$ variations from conventional thermal conductivity measurement method. The higher difference in the case of $\mathrm{Nd}_{2} \mathrm{Ce}_{2} \mathrm{O}_{7}$ material may not be in agreement as much lower thermal conductivity value $\left(\sim 1 \mathrm{~W} / \mathrm{m}^{\circ} \mathrm{K}\right)$ of the $\mathrm{Nd}_{2} \mathrm{Ce}_{2} \mathrm{O}_{7}$ was also found in the literature[45].In comparison to the YSZ (a conventional TBC material), the $\mathrm{CaZrO}_{3},\left(\mathrm{La}_{0.75} \mathrm{Nd}_{0.25}\right)_{2} \mathrm{Zr}_{2} \mathrm{O}_{7}$ and $\mathrm{Nd}_{2} \mathrm{Ce}_{2} \mathrm{O}_{7}$ showed lower thermal conductivity and higher co-efficient of thermal expansion (TEC); being relatively stable at higher temperature $\left(\geq 1500^{\circ} \mathrm{C}\right)$, these materials owned higher potential for application in advanced turbine engines.

\section{References}

[1]W.Ma, et al., Perovskite-Type Strontium Zirconate as a New Material for Thermal Barrier Coatings. J. Am. Ceram. Soc., 91 (2008) 2630-2635.

[2]W. Ma, et al., New Generation Perovskite Thermal Barrier Coating Materials. J. Therm. Spray Technol.,17(2008) 831-837.

[3]J. $\mathrm{Yu}$, et al., Thermal conductivity of plasma sprayed $\mathrm{Sm}_{2} \mathrm{Zr}_{2} \mathrm{O}_{7}$ coatings. J. Eur. Ceram. Soc., 30 (2010) 799-804.

[4]R.Gadow, and M. Lischka, Lanthanum hexaaluminate - novel thermal barrier coatings for gas turbine applications - materials and process development. Surf. Coat. Technol., 151 (2002) 392399.

[5]A.J. Slifka, et al., Thermal conductivity of a zirconia thermal barrier coating. J. Therm. Spray Technol., 7 (1998) 43-46.

[6]C.R.C.Lima, and R. da Exaltacaão Trevisan, Temperature measurements and adhesion properties of plasma sprayed thermal barrier coatings. J. Therm. Spray Technol., 8 (1999) 323-327.

[7]J.Kaspar, and O. Ambroz. Plasma spray coatings as thermal barriers based on zirconium oxide with yttrium oxide. in The 1st Plasma-Technik-Symposium. 1988. Plasma-Technik AG, Wohlen, Switzerland.

[8]Z.-G. Liu, et al., Novel thermal barrier coatings based on rare-earth zirconates/YSZ doubleceramic-layer system deposited by plasma spraying. J. Alloys Compd., 647 (2015) 438-444.

[9]X.Wang, et al., Structural evolution and thermal conductivities of $\left(\mathrm{Gd}_{1-\mathrm{x}} \mathrm{Yb}_{\mathrm{x}}\right)_{2} \mathrm{Zr}_{2} \mathrm{O}_{7}(\mathrm{x}=0,0.02$, 0.04, 0.06, 0.08, 0.1) ceramics for thermal barrier coatings. Ceram. Int., 41 (2015) 12621-12625.

[10]N. Schlegel, et al., Cycling Performance of a Columnar-Structured Complex Perovskite in a Temperature Gradient Test. J. Therm. Spray Technol., 24(2015) 1205-1212.

[11] M.Li, L. Guo, and F. Ye, Phase structure and thermal conductivities of Er2O3 stabilized ZrO2 toughened $\mathrm{Gd}_{2} \mathrm{Zr}_{2} \mathrm{O}_{7}$ ceramics for thermal barrier coatings. Ceram. Int., 42 (2016) 16584-16588.

[12]T. Liu, et al., Properties evolution of plasma-sprayed $\mathrm{La}_{2} \mathrm{Zr}_{2} \mathrm{O}_{7}$ coating induced by pore structure evolution during thermal exposure. Ceram. Int., 42 (2016) 15485-15492.

[13] S. Mahade, et al., Failure analysis of $\mathrm{Gd}_{2} \mathrm{Zr}_{2} \mathrm{O}_{7} / \mathrm{YSZ}$ multi-layered thermal barrier coatings subjected to thermal cyclic fatigue. J. Alloys Compd., 689 (2016) 1011-1019.

[14] B.Paul, et al., Structural properties and the fluorite-pyrochlore phase transition in $\mathrm{La}_{2} \mathrm{Zr}_{2} \mathrm{O}_{7}$ : The role of oxygen to induce local disordered states. J. Alloys Compd., 686 (2016) 130-136.

[15]Z. Xiaofeng, et al., Evolution of microstructure and cyclic life of $\mathrm{La}_{2}\left(\mathrm{Ce}_{0.3} \mathrm{Zr}_{0.7}\right)_{2} \mathrm{O}_{7-3}$ wt.\% $\% \mathrm{Y}_{2} \mathrm{O}_{3}$ coatings. Surf. Coat. Technol.,307 (2016) 951-956.

[16]C. Xiaoge, et al., Thermal conductivity and expansion coefficient of $\mathrm{Ln}_{2} \mathrm{LaTaO}_{7}(\mathrm{Ln}=\mathrm{Er}$ and Yb) oxides for thermal barrier coating applications. Ceram. Int., 42 (2016) 13491-13496. 
[17]D. Zhang, et al., Investigation of a new type of composite ceramics for thermal barrier coatings. Mater. Des., 112 (2016) 27-33.

[18] M.R. Loghman-Estarki, et al., Comparison of hot corrosion behavior of nanostructured ScYSZ and YSZ thermal barrier coatings. Ceram. Int., 42 (2016) 7432-7439.

[19] H.-F.Liu, et al., Hot corrosion behavior of $\mathrm{Sc}_{2} \mathrm{O}_{3}-\mathrm{Y}_{2} \mathrm{O}_{3}-\mathrm{ZrO}_{2}$ thermal barrier coatings in presence of $\mathrm{Na}_{2} \mathrm{SO}_{4}+\mathrm{V}_{2} \mathrm{O}_{5}$ molten salt. Corros. Sci., 85 (2014) p. 87-93.

[20] M.B. Bhatty, F.A. Khalid, and A.N. Khan, Behavior of calcia-stabilized zirconia coating at high temperature, deposited by air plasma spraying system. J. Therm. Spray Technol., 21 (2012) p. 121-131.

[21]R.Ianoş, and P. Barvinschi, Solution combustion synthesis of calcium zirconate, $\mathrm{CaZrO}_{3}$, powders. J. Solid State Chem., 183 (2010) 491-496.

[22]K. Neufuss, et al. Structure and properties of $\mathrm{CaZrO}_{3}$ coatings prepared by WSP and APS spraying. in Thermal Spray 2003: Advancing the Science and Applying the Technology. 2003. Orlando, Florida, USA: ASM International.

[23] M.Pollet, S. Marinel, and G. Desgardin, $\mathrm{CaZrO}_{3}$, a Ni-co-sinterable dielectric material for base metal-multilayer ceramic capacitor applications. J. Eur. Ceram. Soc., 24 (2004) 119-127.

[24] G.Di Girolamo, et al., Evolution of microstructural and mechanical properties of lanthanum zirconate thermal barrier coatings at high temperature. Surf. Coat. Technol., 268 (2015) 298-302.

[25] G. Mauer, et al., Improving Atmospheric Plasma Spraying of Zirconate Thermal Barrier Coatings Based on Particle Diagnostics. J. Therm. Spray Technol., 21 (2012) 363-371.

[26] G. Di Girolamo, et al., Microstructural, mechanical and thermal characteristics of zirconiabased thermal barrier coatings deposited by plasma spraying. Ceram. Int., 41 (2015) 11776-11785.

[27] H. Chen, et al., Thermophysical properties of lanthanum zirconate coating prepared by plasma spraying and the influence of post-annealing. J. Alloys Compd., 486 (2009) 391-399.

[28]X.Q. Cao, R. Vassen, and D. Stoever, Ceramic materials for thermal barrier coatings. J. Eur. Ceram. Soc., 24 (2004) 1-10.

[29]H. Lehmann, et al., Thermal Conductivity and Thermal Expansion Coefficients of the Lanthanum Rare-Earth-Element Zirconate System. J. Am. Ceram. Soc., 86 (2003) 1338-1344.

[30]H. Dai, et al., Neodymium-cerium oxide as new thermal barrier coating material. Surf. Coat. Technol., 20 (2006) 2527-2533.

[31]H.Wang, and R. Dinwiddie, Reliability of laser flash thermal diffusivity measurements of the thermal barrier coatings. J. Therm. Spray Technol., 9 (2000) 210-214.

[32]X.Guo, et al., Image-based multi-scale simulation and experimental validation of thermal conductivity of lanthanum zirconate. Int. J. Heat Mass Transfer, 100 (2016) 34-38.

[33] R.Taylor, Thermal conductivity determinations of thermal barrier coatings. Mater. Sci. Eng., A, 245 (1998) 160-167.

[34]J.F.Bisson, et al., Thermal conductivity of yttria-zirconia single crystals, determined with spatially resolved infrared thermography. J. Am. Ceram. Soc., 83 (2000) 1993-1998.

[35] T.Sakagami, and S. Kubo, Applications of pulse heating thermography and lock-in thermography to quantitative nondestructive evaluations. Infrared Phys. Technol., 43 (2002) 211218.

[36]F. Cernuschi, et al., Thermal diffusivity measurements by photothermal and thermographic techniques. Int. J. Thermophys., 25 (2004) 439-457. 
[37]J. Sun, Thermal Property Measurement for Thermal Barrier Coatings by Thermal Imaging Method. Advanced Ceramic Coatings and Interfaces V: Ceramic Engineering and Science Proceedings, 31 (2010) 87-94.

[38] C.P. Camirand, Measurement of thermal conductivity by differential scanning calorimetry. Thermochim. Acta, 47 (2004) 1-4.

[39] G. Hakvoort, L. Van Reijen, and A. Aartsen, Measurement of the thermal conductivity of solid substances by DSC. Thermochim. Acta, 93 (1985) 317-320.

[40]C.A. Dai, Y.F. Chen, and M.W. Liu, Thermal properties measurements of renatured gelatin using conventional and temperature modulated differential scanning calorimetry. J. Appl. Polym. Sci., 99 (2006) 1795-1801.

[41]C.M.Lopes, and M.I. Felisberti, Thermal conductivity of PET/(LDPE/AI) composites determined by MDSC. Polym. Test., 23 (2004) 637-643.

[42] S.M. Marcus, and R.L. Blaine, Thermal conductivity of polymers, glasses and ceramics by modulated DSC. Thermochim. Acta, 243 (1994) 231-239.

[43]X.Cao, et al., New double-ceramic-layer thermal barrier coatings based on zirconia-rare earth composite oxides. J. Eur. Ceram. Soc., 26 (2006) 247-251.

[44] R. Vassen, et al., Zirconates as New Materials for Thermal Barrier Coatings. J. Am. Ceram. Soc., 83 (2000) 2023-2028.

[45]X. Zhong, et al., Phase stability and thermophysical properties of neodymium cerium composite oxide. J. Alloys Compd., 469 (2009) 82-88.

[46]Z.-G.Liu, et al., Effect of Ti substitution for $\mathrm{Zr}$ on the thermal expansion property of fluoritetype $\mathrm{Gd}_{2} \mathrm{Zr}_{2} \mathrm{O}_{7}$. Mater. Des., 30 (2009) 3784-3788.

[47] C.U.Hardwicke, and Y.-C. Lau, Advances in thermal spray coatings for gas turbines and energy generation: a review. J. Therm. Spray Technol., 22 (2013) 564-576.

[48] J.Wu, et al., Low-Thermal-Conductivity Rare-Earth Zirconates for Potential Thermal-BarrierCoating Applications. J. Am. Ceram. Soc., 85 (2002) 3031-3035. 